\title{
Studi Pemangkasan dan Aplikasi Sitokinin-Giberelin pada Tanaman Teh (Camellia sinensis (L.) O. Kuntze) Produktif Klon GMB 7
}

\section{Study of Pruning and Cytokinin-Giberelin Applications on Productive Tea Plant (Camellia sinensis (L.) O. Kuntze) GMB 7 Clone}

\section{Intan Ratna Dewi Anjarsari', Jajang Sauman Hamdani ${ }^{1}$, Cucu Suherman ${ }^{1}$, Tati Nurmala ${ }^{1}$, Heri Syahrian Khomaeni ${ }^{2}$, dan Vitria Puspitasari Rahadi ${ }^{2}$}

${ }^{1}$ Departemen Budidaya, Fakultas Pertanian, Universitas Padjadjaran

J1. Raya Bandung-Sumedang Km 21 Jatinagor 40600, Bandung, Indonesia

${ }^{2}$ Pusat Penelitian Teh dan Kina (PPTK) Gambung Ciwidey, Bandung, Indonesia

Diterima 9 Agustus 2020/Disetujui 4 Maret 2021

\begin{abstract}
Pruning of tea plants is carried out in productive tea plantations with varying types and heights of pruning. Pruning causes most or all of the photosynthetic organs of the plant to be lost, and regrowth of new shoots takes about 2-3 months. The addition of cytokinins benzyl amino purine (BAP) and gibberellin (GA) is expected to accelerate shoot growth after pruning. The purpose of this study was to determine the effect of pruning, BAP and GA application on the growth and yield of tea shoots after pruning. The experiment was carried out in Tea and Cinchona Gambung Research Center from August 2017 to October 2018 using a split split plot design consisting of type of pruning as the main plot (clean pruning and lung pruning), pruning height $(40 \mathrm{~cm}, 50 \mathrm{~cm}$, and $60 \mathrm{~cm})$ as the subplot, BAP and GA application as the sub-sub plot (0 ppm, 60 ppm BAP, 50 ppm GA, 60 ppm BAP + 50 ppm GA). The results showed that clean pruning and 60 ppm BAP +50 ppm GA produced the best growth on shoots height. Pruning height of $60 \mathrm{~cm}$ and 60 ppm BAP showed the highest leaf chlorophyll index of third months as much as 91.58 (higher compared to previous research results of 62.5-75.28), while the pruning height of $60 \mathrm{~cm}$ and $60 \mathrm{ppm} B A P+50 \mathrm{ppm}$ GA produced the highest fresh shoot weight per shrub. Individually, $50 \mathrm{~cm}$ pruning height reduced the number of dormant shoots and $50 \mathrm{ppm}$ GA shortened the length of shoot dormancy to 22 days.
\end{abstract}

Keywords: banji shoots, productive tea, shoots dormancy

\section{ABSTRAK}

Pemangkasan pada tanaman teh yang dilakukan di kebun teh produktif menyebabkan sebagian besar atau secara keseluruhan organ fotosintesis tanaman hilang dan diperlukan waktu sekitar 2-3 bulan utuk tumbuh kembali. Pemangkasan dilakukan dengan jenis dan tinggi pangkasan yang bervariasi. Penambahan sitokinin benzil amino purine (BAP) dan giberelin (GA) diharapkan dapat mempercepat pertumbuhan pucuk setelah dipangkas. Tujuan penelitian adalah mempelajari pengaruh pemangkasan serta aplikasi BAP dan GA terhadap pertumbuhan dan hasil pucuk teh. Percobaan dilaksanakan kebun percobaan Pusat Penelitian Teh dan Kina Gambung bulan Agustus 2017-Oktober 2018 menggunakan rancangan split-split plot terdiri dari jenis pemangkasan (pemangkasan bersih dan pemangkasan ajir) sebagai petak utama, tinggi pangkasan sebagai anak petak $(40 \mathrm{~cm}, 50 \mathrm{~cm}$, dan $60 \mathrm{~cm})$, aplikasi BAP dan GA sebagai anak-anak petak $(0$ ppm, 60 ppm BAP, 50 ppm GA, 60 ppm BAP+ 50 ppm GA). Hasil penelitian menunjukkan bahwa pemangkasan bersih dan 60 ppm BAP + 50 ppm GA menghasilkan pertumbuhan terbaik pada tinggi tunas. Tinggi pangkasan $60 \mathrm{~cm}$ dan 60 ppm BAP menunjukkan indeks klorofil daun tertinggi bulan ke-3 sebesar 91.58 (lebih tinggi daripada hasil penelitian sebelumnya yaitu 62.5-75.28), sedangkan tinggi pangkasan $60 \mathrm{~cm}$ dan 60 ppm BAP + 50 ppm GA memberikan bobot basah pucuk per perdu tertinggi pada pemetikan produksi. Secara tunggal, tinggi pangkasan $50 \mathrm{~cm}$ menurunkan jumlah pucuk burung serta 50 ppm GA mempersingkat lamanya masa dormansi pucuk menjadi 22 hari.

Kata kunci: dormansi pucuk, pucuk burung, teh produktif

\footnotetext{
* Penulis untuk korespondensi. e-mail: intan.ratna@unpad.ac.id
} 


\section{PENDAHULUAN}

Hasil teh secara signifikan tergantung pada bentuk perdu. Pemangkasan pada tanaman teh produktif bertujuan membentuk perdu yang baik melalui perbaikan percabangan, mempermuda umur jaringan dan menurunkan bidang petik. Pemangkasan akan menginisiasi banyak cabang lateral dari bagian bawah batang, selanjutnya akan meningkatkan jumlah cabang pemangkasan Pemilihan jenis, ketinggian dan waktu pemangkasan akan sangat menentukan keberhasilan pemangkasan. Hal ini ditandai dengan jangka waktu antara tanaman setelah dipangkas hingga menumbuhkan kembali tunas baru tidak terlalu lama. Menurut Ahmad et al. (2014) pemangkasan pada waktu yang tepat dapat meningkatkan produktivitas pucuk.

Pemilihan jenis pemangkasan dan ketinggian pemangkasan akan menentukan kecepatan pertumbuhan teh berikutnya. Jenis pemangkasan yang tepat untuk tanaman teh produktif adalah jenis pemangkasan bersih dan pemangkasan ajir atau jambul. Pemangkasan ajir atau jambul menyisakan ranting disisi kiri dan kanan perdu agar selama proses pemulihan setelah dipangkas tanaman masih dapat berfotosintesis (Mphagwe, 2009). Pemangkasan bersih dapat dilakukan pada musim hujan dan dilakukan di kebun teh yang umumnya berada di dataran tinggi. Pemangkasan bersih dianjurkan dilakukan saat kadar air cukup dan kondisi ini dapat terjadi saat musim hujan karena pada saat pemangkasan bersih semua organ fotosintesis dibuang dan tanaman hanya mengandalkan cadangan pati dalam akar untuk pertumbuhannya.

Ketinggian pemangkasan juga merupakan faktor penting yang perlu diperhatikan dalam pemangkasan. Pemangkasan pada perdu teh umumnya dilakukan pada ketinggian yang berbeda $(50-60 \mathrm{~cm})$ sesuai dengan kondisi agroekologis (Ebanoidze dan Kutelia, 2018). Hasil penelitian Saikia dan Baruah (2013) menunjukkan bahwa pada ketinggian pemangkasan $50 \mathrm{~cm}$ menghasilkan daun yang sehat dan hasil tanaman yang lebih tinggi. Selain jenis dan ketinggian pangkasan, pemulihan perdu teh dari pemangkasan bergantung pada kesehatan perdu dalam hal ini kadar pati di akar. Oleh karena itu, agar diperoleh hasil yang baik dalam pemangkasan, tanaman teh yang akan dipangkas sebaiknya dalam keadaan kesehatan yang optimal, yaitu harus mempunyai makanan cadangan yang cukup sekitar 12\% (Santoso, 2007). Pemangkasan dapat menyebabkan kematian akar pada beberapa kondisi karena pasokan karbohidrat tidak memadai (Chesney dan Vasquez, 2012). Dengan demikian penentuan kadar pati akar, kondisi lingkungan serta status hara sebelum pemangkas diperlukan agar meminimalisasi tingkat kematian perdu teh (Anjarsari et al., 2018).

Perkembangan bidang petik dan pertumbuhan tunas sebagai bakal pucuk teh setelah pemangkasan pada umumnya terjadi secara alami tanpa penambahan zat pengatur tumbuh (ZPT). Sitokinin adalah hormon esensial untuk pertumbuhan dan perkembangan tanaman, merupakan kelas turunan purin berperan mengontrol berbagai proses perkembangan sepanjang siklus hidup tumbuhan, termasuk gametogenesis, spesifikasi meristem akar, perkembangan vaskular, pertumbuhan pucuk dan akar, homeostasis meristem, penuaan daun (Zurcher dan Muller, 2016). Selain itu, cytokinin memediasi respons terhadap isyarat lingkungan seperti cahaya, stres, dan kondisi nutrisi juga berperan dalam transisi etioplas ke kloroplas (Cortleven dan Schmulling, 2015).

Tunas samping yang tertekan pertumbuhannya disebabkan antara lain oleh keadaaan kahat sitokinin (Salisbury dan Ross, 1995). Menurut Mazid et al. (2011) sitokinin berinteraksi secara kompleks untuk mengontrol berbagai aspek yang berkaitan dengan pertumbuhan, perkembangan serta diferensiasi dan jika terjadi defisensi menyebabkan perubahan perkembangan pleiotropik seperti penurunan tunas dan peningkatan pertumbuhan akar.

Sitokinin diberikan kepada tunas yang dorman, menginisisasi aktivitas mitosis dan tunas mulai tumbuh. Aplikasi sitokinin berperan dalam pengembangan struktur tajuk (Autio dan Day, 2016) menunjukkan bahwa penggunaan fitohormonal memiliki potensi besar untuk lebar tajuk terutama setelah dipangkas. Pemberian sitokinin pada tanaman teh setelah dipangkas akan meningkatkan pertumbuhan tunas lateral. Menurut Kebrom et al. (2013) arsitektur tajuk tanaman ditentukan oleh meristem apikal primer dan cabang lateral turunannya. Jumlah cabang lateral memiliki pengaruh yang besar terhadap hasil, pada tanaman teh banyaknya cabang lateral membuat bidang petik semakin lebar dan memungkinkan banyak bakal tunas yang tumbuh.

Zat pengatur tumbuh lainnya yang digunakan adalah Giberelin (GA). Giberelin merupakan zat pengatur tumbuh yang mengatur banyak aspek pertumbuhan dan perkembangan tanaman (Binenbaum et al., 2018). Menurut Nagar dan Kumar (2000) efek GA terkonjugasi menurun pada saat pucuk teh dalam kondisi dorman. Pertumbuhan pucuk dormansi (pucuk burung) yang lebih banyak dibandingkan pucuk peko akan menurunkan kualitas teh. Pemberian 3\% dan 4\% GA berpengaruh positif terhadap parameter tinggi tanaman, jumlah cabang, luas daun dan biomassa segar (Maudu et al., 2011). Aplikasi Benzil Amino Purine (BAP) dan Giberelin (GA) pada tanaman produktif dianggap perlu dengan pertimbangan bahwa penambahan ZPT ini dapat memacu pertumbuhan cabang lateral dan tunas serta penggunaan giberelin untuk memecahkan dormansi pucuk. Penelitian ini bertujuan untuk mempelajari pengaruh pemangkasan dan aplikasi BAP dan GA terhadap pertumbuhan dan hasil teh di kebun produktif.

\section{BAHAN DAN METODE}

Penelitian dilaksanakan di Kebun Pusat Penelitian Teh dan Kina Gambung pada bulan Agustus 2017 sampai Oktober 2018. Bahan tanaman yang digunakan tanaman teh produktif klon GMB 7 (umur 7 tahun) sebanyak 960 tanaman (satu plot sebanyak 10 tanaman) dengan jarak tanam $110 \mathrm{~cm}$ x $90 \mathrm{~cm}$, BAP, GA3, air. Alat-alat yang digunakan di lapangan adalah alat pangkas, sprayer, waring, timbangan, hand counter, amplop kertas, oven untuk mengeringkan sampel pucuk, timbangan analitik, dan klorofilmeter tipe SPAD. 
Pemangkasan dilakukan satu kali (pemangkasan ajir dan pemangkasan bersih) dilakukan pada bulan Oktober 2017 sedangkan aplikasi BAP dan GA dilakukan setelah pemangkasan dengan interval 14 hari sekali dengan disemprotkan merata pada perdu teh hingga periode pemetikan produksi (Agustus 2017-Oktober 2018) yang dilakukan sebanyak enam kali. Satu plot dengan ukuran 20 $\mathrm{m}^{2}$ memerlukan air sebanyak 3 liter (setelah kalibrasi).

Rancangan analisis menggunakan split split plot terdiri atas jenis pemangkasan sebagai petak utama, tinggi pangkasan sebagai anak petak dan aplikasi ZPT sebagai anak-anak petak. Petak utama terdiri atas 2 taraf jenis pangkasan yaitu pangkasan bersih (J1) dan pangkasan ajir (J2). Anak petak terdiri atas 3 taraf tinggi pangkasan : $40 \mathrm{~cm}$ (P1), $50 \mathrm{~cm}(\mathrm{P} 2), 60 \mathrm{~cm}(\mathrm{P} 3)$. Anak anak petak terdiri atas 4 taraf aplikasi ZPT : tanpa ZPT (Z1), 60 ppm BAP (Z2), 50 ppm GA (Z3), 60 ppm BAP+ 50 ppm GA (Z4).

Karakter yang diamati dan diukur setelah aplikasi ZPT meliputi: (1) Tinggi tunas dilakukan dengan selang waktu 7 hari sekali setelah pemangkasan sampai menjelang tumbuhnya pucuk peko dilakukan selama dua bulan pertama setelah tanaman teh dipangkas. (2) Jumlah pucuk burung dihitung pada cabang atau ranting dengan interval 7 hari sekali. (3) Dormansi pucuk (hari), dilakukan dengan mengamati setiap hari saat keluarnya pucuk burung berumur satu hari sampai akhir masa pucuk burung selama periode pemetikan produksi ( 3 bulan) pada sampel tanaman yang sudah ditandai. (4) Indeks klorofil daun dilakukan pada daun indung menggunakan klorofil meter tipe SPAD dengan interval 14 hari sekali. Daun indung atau mother leaf adalah daun tua pertama tempat percabangan pucuk yang sehat yang telah siap dipetik, berwarna hijau gelap yang telah mencapai ukuran penuh bila dibandingkan dengan daundaun tua di bawahnya dan terletak di ketiak tunas yang sedang tumbuh. (5) Bobot basah pucuk pemetikan produksi, dihitung dengan cara menimbang bobot basah pucuk setiap kali pemetikan dengan daur petik 14 hari sekali. Pengamatan dilakukan sebanyak enam kali.

Analisis statistik menggunakan STAR (Statistical Tool for Agricutural Research). Bila perlakuan hasil analisis ragam menunjukkan keragaman yang berbeda nyata, dilanjutkan dengan Uji Duncan pada taraf kepercayaan 95\% (Gasperz,1995).

\section{HASIL DAN PEMBAHASAN}

\section{Tinggi Tunas}

Hasil analisis menunjukkan terdapat pengaruh interaksi antara jenis pemangkasan bersih dan konsentrasi ZPT terhadap tinggi tunas minggu ke-4. Pada pemangkasan bersih dan 60 ppm BAP + 50 ppm GA menyebabkan jumlah tunas tertinggi dibandingkan perlakuan lainnya (Tabel 1). Sebaliknya pada pemangkasan ajir dan aplikasi ZPT pada berbagai taraf konsentrasi tidak memberikan pengaruh nyata terhadap tinggi tunas. Hal ini disebabkan kehadiran ajir (ranting teh disertai daun) pada awal pertumbuhan tunas setelah dipangkas menyebabkan pertumbuhan tunas terganggu karena aliran pati untuk pertumbuhan tunas baru tidak sepenuhnya dialirkan ke tunas namun ada alokasi menuju ranting ajir. Pemotongan ranting ajir dilakukan pada saat menjelang pemetikan jendangan.

Sitokinin adalah hormon tanaman yang esensial untuk merangsang pembelahan sel, mengatur ukuran meristem pucuk, jumlah primordia daun, dan pertumbuhan daun dan pucuk. Sitokinin dapat menstimulasi diferensiasi dan perkembangan tunas aksilar (Hwang et al., 2012). Menurut Zhang et al. (2018) perlakuan 6-Benzyladenine juga meningkatkan panjang tunas lateral (atau cabang) dan diameter cabang lateral pada tanaman teh 5 bulan setelah pemangkasan. Munculnya tunas dan pertumbuhan tanaman teh dipengaruhi oleh adanya faktor internal sifat genetik dan komposisi hormon pada tanaman untuk mempercepat dan merangsang pemanjangan sel dan batang yang lebih banyak, dibantu oleh hormon giberelin dan faktor eksternal (lingkungan) (Roman et al., 2016). Aktivitas sitokinin adalah elemen kunci dalam membangun dan mengatur pembelahan sel di shoot apical meristem (SAM), dengan penelitian genetik yang menunjukkan bahwa sitokinin adalah regulator positif proliferasi sel di SAM (Kieber dan Schaller, 2014).

Giberelin berperan mengatur pembelahan sel dan ekspansi untuk mengontrol perpanjangan pucuk atau tunas serta memperbaiki struktur kanopi (Rademacher, 2016). Hasil penelitian Yue et al. (2018) menunjukkan bahwa GA merupakan fitohormon fundamental yang mengatur pertumbuhan dan perkembangan tanaman secara ekstensif,

Tabel 1. Pengaruh interaksi jenis pangkasan dan aplikasi ZPT terhadap tinggi tunas tanaman teh

\begin{tabular}{lcccc}
\hline \multirow{2}{*}{ Jenis pemangkasan } & \multicolumn{3}{c}{ Tinggi tunas $(\mathrm{cm})$} \\
\cline { 2 - 5 } & $0 \mathrm{ppm}$ & $60 \mathrm{ppm} \mathrm{BAP}$ & $50 \mathrm{ppm} \mathrm{GA}$ & $60 \mathrm{ppm} \mathrm{BAP}+50 \mathrm{ppm}$ GA \\
\hline Pemangkasan bersih & $12.78 \mathrm{bB}$ & $16.17 \mathrm{bAB}$ & $16.76 \mathrm{bA}$ & $19.16 \mathrm{aA}$ \\
Pemangkasan ajir & $15.89 \mathrm{bA}$ & $16.16 \mathrm{bA}$ & $12.70 \mathrm{bB}$ & $12.88 \mathrm{bB}$ \\
\hline
\end{tabular}

Keterangan: Angka rata-rata yang ditandai dengan huruf yang sama (huruf besar arah horisontal dan huruf kecil arah vertikal) tidak berbeda nyata menurut uji Duncan taraf 5\% 
terutama dormansi tunas dan transisi tunas pada teh sebagai tanaman tahunan. Giberelin merangsang pemanjangan sel dengan mengubah sifat dinding sel; sebagai akibatnya, potensi air sel diturunkan memungkinkan untuk pengambilan air dan karenanya peningkatan volume sel (Jones dan Kaufman, 2008).

\section{Jumlah Pucuk Burung dan Lamanya Dormansi Pucuk}

Hasil analisis statistik menunjukkan bahwa terdapat pengaruh tunggal tinggi pangkasan terhadap jumlah pucuk burung. Perlakuan tinggi pangkasan $50 \mathrm{~cm}$ menunjukkan pertumbuhan jumlah pucuk burung lebih rendah dibandingkan perlakuan $40 \mathrm{~cm}$ dan $60 \mathrm{~cm}$. Selanjutnya hasil analisis menunjukkan bahwa terdapat pengaruh tunggal konsentrasi ZPT yakni perlakuan 50 ppm GA dan perlakuan 60 ppm BAP +50 ppm GA dapat menurunkan lamanya dormansi pucuk. Jenis pangkasan baik pangkasan bersih maupun pangkasan ajir tidak memberikan pengaruh terhadap jumlah pucuk burung maupun lamanya dormansi pucuk (Tabel 2).

Waktu pecah dormansi pucuk tercepat ditunjukkan pada perlakuan $50 \mathrm{ppm}$ GA dan tidak berbeda nyata dengan 60 ppm BAP + 50 ppm GA, disusul perlakuan 60 ppm BAP. Perlakuan 50 ppm GA ataupun 60 ppm BAP +50 ppm GA pada penelitian ini secara signifikan mempercepat waktu pemecahan dormansi hal ini berkaitan dengan peran GA dan BAP dapat memecahkan fase dormansi pada tanaman teh. Hasil penelitian ini menunjukkan lamanya dormansi sekitar 21 sampai 25 hari sedangkan lama dormansi umumnya 60 hari.

Dormansi tunas atau pucuk merupakan bentuk adaptasi tanaman tahunan (perennial) untuk bertahan hidup dalam kondisi lingkungan yang kurang menguntungkan dan hormon tanaman merupakan mediator yang berperan dalam proses dormansi (Liu dan Sherif, 2019). Dormansi

Tabel 2. Pengaruh tunggal tinggi pangkasan dan konsentrasi ZPT terhadap jumlah pucuk burung dan lamanya dormansi pucuk teh (hari)

\begin{tabular}{lcc}
\hline Perlakuan & $\begin{array}{c}\text { Jumlah } \\
\text { pucuk } \\
\text { burung }\end{array}$ & $\begin{array}{c}\text { Lamanya } \\
\text { dormansi } \\
\text { pucuk (hari) }\end{array}$ \\
\hline Tinggi pangkasan & & \\
$40 \mathrm{~cm}$ & $3.0 \mathrm{a}$ & $23.25 \mathrm{~b}$ \\
$50 \mathrm{~cm}$ & $2.6 \mathrm{~b}$ & $23.00 \mathrm{~b}$ \\
$60 \mathrm{~cm}$ & $3.2 \mathrm{a}$ & $23.19 \mathrm{~b}$ \\
Aplikasi ZPT & & \\
0 ppm & $2.9 \mathrm{~b}$ & $25.25 \mathrm{a}$ \\
60 ppm BAP & $3.0 \mathrm{~b}$ & $23.00 \mathrm{~b}$ \\
50 ppm GA & $2.8 \mathrm{~b}$ & $21.67 \mathrm{c}$ \\
60 ppm BAP +50 ppm GA & $3.0 \mathrm{~b}$ & $22.67 \mathrm{bc}$ \\
\hline
\end{tabular}

Keterangan: Angka rata-rata yang ditandai dengan huruf yang sama pada kolom yang sama tidak berbeda nyata menurut uji Duncan taraf 5\% pucuk berkaitan dengan pertumbuhan pucuk burung pada siklus pertumbuhan tanaman teh. Pucuk burung atau pucuk dorman adalah tunas yang tidak aktif terletak pada ujung pucuk. Mekanisme pemecahan dormansi pada pucuk teh berkaitan dengan peran GA adalah bahwa GA eksogen menginisiasi transportasi hasil fotosintesis dari daun ke tunas melalui regulasi hubungan sink dan source. Fotosintat yang diproduksi di daun pemeliharaan memiliki banyak kegunaan di dalam daun dan juga diubah sebagai sukrosa ke organ non fotosintetik seperti pucuk baru. Proses yang menentukan berapa banyak karbon yang dialokasikan untuk setiap penggunaan disebut fotosintat atau partisi karbon. Setelah tiba di sink, fotosintat dipartisi lagi untuk digunakan sebagai sumber energi bagi pertumbuhan pucuk (Halford, 2010).

Pemberian zat pengatur tumbuh pada tanaman teh untuk menginisiasi munculnya tunas dan pertumbuhan pucuk telah dilakukan diantaranya oleh Yoshimitsu (1970) yaitu pemberian giberelin (GA) berpengaruh terhadap pertumbuhan dan perkembangan pucuk. Penyemprotan dengan GA pada awal pertumbuhan dimusim semimembantu memecahkan masa dormansi tunas dan menginisiasi lebih awal tumbuhnya tunas dibandingkan yang tidak diberi perlakuan GA. Selanjutnya penelitian yang dilakukan oleh Krishnaraj et al. (2020) yang menunjukkan aplikasi GA yang disemprotkan ke daun membantu meningkatkan kualitas dan kuantitas produksi teh dengan cara memecah dormansi dan merangsang pertumbuhan tunas. Reaktivasi meristem dorman pada pucuk banjhi (pucuk dorman atau pucuk burung) penting dilakukan untuk meningkatkan kualitas dan kuantitas produksi teh.

Faktor lain yang mempengaruhi lamanya masa dormansi lainnya adalah faktor cuaca, merupakan faktor penting yang mempengaruhi masa dormansi pucuk seperti suhu dan curah hujan (De Costa et al., 2007). Data hasil pengamatan suhu di Pusat Penelitian Teh dan Kina menunjukkan pada bulan Juli suhu maksimum $26.3{ }^{\circ} \mathrm{C}$ dan suhu minimum $13.8^{\circ} \mathrm{C}$ dengan suhu rata-rata kisaran antara $18.9^{\circ} \mathrm{C}$. Di samping itu kondisi di bulan Agustus 2018 masih terjadi musim kemarau dengan suhu cukup tinggi dan curah hujan rendah. Umumnya pada kondisi kekeringan tanaman teh cenderung menumbuhkan lebih banyak pucuk burung dibandingkan peko. Namun kecenderungan jumlah peko lebih banyak diduga penambahan BAP dan GA berpengaruh positif untuk memperpendek masa dormansi pucuk.

\section{Indeks Kandungan Klorofil Daun}

Hasil analisis indeks kandungan klorofil daun menunjukkan terdapat pengaruh interaksi antara tinggi pangkasan dan konsentrasi ZPT terhadap indeks klorofil daun pada pengamatan bulan ke-1, ke-2 dan ke-3 (Tabel 3, 4, dan 5), namun jenis pangkasan baik bersih maupun ajir tidak memberikan pengaruh nyata terhadap indeks klorofil daun. Pada pengamatan bulan ke-1 (Tabel 3) menunjukkan tinggi pangkasan $40 \mathrm{~cm}$ dan 60 ppm BAP menunjukkan indeks klorofil daun lebih tinggi dibandingkan perlakuan lainnya, namun tidak berbeda nyata dengan perlakuan tinggi pangkasan $50 \mathrm{~cm}$ dan 50 ppm GA serta $60 \mathrm{~cm}$ dan 50 
Tabel 3. Pengaruh interaksi tinggi pangkasan dan konsentrasi ZPT terhadap indeks kandungan klorofil daun (cci) pada bulan ke-1 pada tanaman teh

\begin{tabular}{ccccc}
\hline \multirow{2}{*}{ Tinggi pangkasan } & \multicolumn{4}{c}{ Indeks kandungan klorofil bulan ke-1 (cci) } \\
\cline { 2 - 5 } & $0 \mathrm{ppm}$ & $60 \mathrm{ppm} \mathrm{BAP}$ & $50 \mathrm{ppm} \mathrm{GA}$ & $60 \mathrm{ppm} \mathrm{BAP}+50 \mathrm{ppm} \mathrm{GA}$ \\
\hline $40 \mathrm{~cm}$ & $85.70 \mathrm{bAB}$ & $92.58 \mathrm{aA}$ & $86.25 \mathrm{bA}$ & $84.77 \mathrm{bB}$ \\
$50 \mathrm{~cm}$ & $82.26 \mathrm{bB}$ & $87.99 \mathrm{aAB}$ & $89.05 \mathrm{aA}$ & $86.40 \mathrm{aB}$ \\
$60 \mathrm{~cm}$ & $88.55 \mathrm{aA}$ & $87.43 \mathrm{aB}$ & $87.80 \mathrm{aAB}$ & $85.76 \mathrm{abB}$ \\
\hline
\end{tabular}

Keterangan: Angka rata-rata yang ditandai dengan huruf yang sama (huruf besar arah horisontal dan huruf kecil arah vertikal) tidak berbeda nyata menurut uji Duncan taraf 5\%; cci = chlorophyl content index

ppm GA. Demikian pula pada bulan ke-2 (Tabel 4) terdapat pengaruh antara tinggi pangkasan $40 \mathrm{~cm}$ dan 60 ppm BAP terhadap indeks klorofil daun (90.54), namun tidak berbeda nyata dengan perlakuan tinggi pangkasan $60 \mathrm{~cm}$ dan $60 \mathrm{ppm}$ BAP ( 91.58). Pada bulan ke-3 (Tabel 5) terdapat pengaruh antara tinggi pangkasan $60 \mathrm{~cm}$ dan 60 ppm BAP yang menunjukkan indeks klorofil daun tertinggi dibandingkan perlakuan lainnya sebesar 91.58 bila dibandingkan dengan indeks klorofil teh hasil penelitian sebelumnya sebesar 62.575.28 (Liu et al., 2012). .

Ketinggian pangkasan $40 \mathrm{~cm}$ cukup berat bagi perdu teh untuk menumbuhkan kembali daun baru, namun dengan penambahan BAP 60 ppm tampaknya secara tidak langsung dapat meningkatkan indeks kandungan klorofil. Boonman dan Pons (2007) menyimpulkan bahwa kandungan pigmen dipengaruhi oleh interaksi cahaya dan konsentrasi sitokinin. Sitokinin berperan dalam pengembangan kloroplas, aplikasi sitokinin mengarah pada akumulasi klorofil dan meningkatkan konversi etioplast menjadi kloroplas. Tinggi pangkasan $60 \mathrm{~cm}$ sesuai untuk diaplikasikan agar cadangan pati yang hilang tidak terlalu banyak untuk pertumbuhan pucuk dan perkembangan daun pemeliharaan. Di samping pengaruh faktor perlakuan, nilai indeks klorofil daun dapat dipengaruhi oleh faktor internal (metabolisme tanaman) maupun ekternal berkaitan dengan intensitas penyinaran matahari optimal dalam mendukung proses fotosintesis.

Menurut Santoso et al. (2014) bahwa pemangkasan merupakan dasar manipulasi bentuk dan struktur kanopi yang ideal bagi terciptanya lingkungan dan sekaligus proses metabolisme dalam tanaman, salah satunya fotosintesis. Daun pemeliharaan bekerja sebagai "pabrik" yang terus melaksanakan proses fotosintesis, sehingga tanaman akan tetap mendapat "makanan" berupa zat pati sebagai hasil dari proses tersebut. Daun pemeliharaan merupakan mesin fotosintesis pada tanaman teh dimana pada daun tersebut terkandung klorofil sebagai elemen kunci dari fotosintesis, salah satu yang diperlukan untuk penyerapan cahaya (Hörtensteiner dan Kräutler, 2011).

Tabel 4. Pengaruh interaksi tinggi pangkasan dan konsentrasi ZPT terhadap indeks kandungan klorofil daun (cci) pada bulan ke-2 pada tanaman teh

\begin{tabular}{ccccc}
\hline \multirow{2}{*}{ Tinggi pangkasan } & \multicolumn{4}{c}{ Indeks kandungan klorofil bulan ke-2 (cci) } \\
\cline { 2 - 5 } & $0 \mathrm{ppm}$ & $60 \mathrm{ppm} \mathrm{BAP}$ & $50 \mathrm{ppm} \mathrm{GA}$ & $60 \mathrm{ppm} \mathrm{BAP}+50 \mathrm{ppm}$ GA \\
\hline $40 \mathrm{~cm}$ & $87.42 \mathrm{bB}$ & $90.86 \mathrm{aA}$ & $88.46 \mathrm{abA}$ & $86.61 \mathrm{bB}$ \\
$50 \mathrm{~cm}$ & $87.33 \mathrm{bB}$ & $85.49 \mathrm{bB}$ & $85.32 \mathrm{bB}$ & $87.49 \mathrm{bB}$ \\
$60 \mathrm{~cm}$ & $84.83 \mathrm{bB}$ & $90.54 \mathrm{aA}$ & $86.69 \mathrm{bAB}$ & $88.06 \mathrm{abB}$ \\
\hline
\end{tabular}

Keterangan: Angka rata-rata yang ditandai dengan huruf yang sama (huruf besar arah horisontal dan huruf kecil arah vertikal) tidak berbeda nyata menurut uji Duncan taraf 5\%; cci = chlorophyl content index

Tabel 5. Pengaruh interaksi tinggi pangkasan dan konsentrasi ZPT terhadap indeks kandungan klorofil daun (cci) pada bulan ke-3 pada tanaman teh

\begin{tabular}{lcccc}
\hline \multirow{2}{*}{ Tinggi pangkasan } & \multicolumn{4}{c}{ Indeks kandungan klorofil bulan ke-3 (cci) } \\
\cline { 2 - 5 } & $0 \mathrm{ppm}$ & $60 \mathrm{ppm} \mathrm{BAP}$ & $50 \mathrm{ppm} \mathrm{GA}$ & $60 \mathrm{ppm} \mathrm{BAP}+50 \mathrm{ppm} \mathrm{GA}$ \\
\hline $40 \mathrm{~cm}$ & $88.06 \mathrm{aA}$ & $86.97 \mathrm{bAB}$ & $86.32 \mathrm{bAB}$ & $84.14 \mathrm{bB}$ \\
$50 \mathrm{~cm}$ & $84.00 \mathrm{bB}$ & $86.88 \mathrm{bB}$ & $89.13 \mathrm{bA}$ & $85.72 \mathrm{bB}$ \\
$60 \mathrm{~cm}$ & $87.75 \mathrm{abB}$ & $91.58 \mathrm{aA}$ & $88.25 \mathrm{bB}$ & $87.25 \mathrm{bB}$ \\
\hline
\end{tabular}

Keterangan: Angka rata-rata yang ditandai dengan huruf yang sama (huruf besar arah horisontal dan huruf kecil arah vertikal) tidak berbeda nyata menurut uji Duncan taraf 5\%. cci $=$ chlorophyl content index 
Klorofil merupakan komponen kloroplas yang utama dan kandungan klorofil relatif berkorelasi positif dengan laju fotosintesis (Li et al., 2016). Menurut Davies (2010) sitokinin dapat berperan dalam perluasan daun, yang dihasilkan dari pembesaran sel.

\section{Bobot Basah Pucuk Pemetikan Produksi}

Hasil analisis statistik menunjukkan terdapat pengaruh interaksi antara tinggi pangkasan dengan konsentrasi GA terhadap bobot basah pucuk, namun jenis pangkasan baik pangkasan bersih maupun ajir tidak memberikan pengaruh interaksi terhadap bobot basah pucuk (Tabel 6 dan 7).

Perlakuan tinggi pangkasan 60 disertai 50 ppm GA menunjukkan pengaruh interaksi terhadap bobot basah produksi namun tidak berbeda nyata dengan perlakuan tinggi pangkasan $40 \mathrm{~cm}$ dan $50 \mathrm{ppm}$ GA. Hal ini menunjukkan bahwa baik tinggi pangkasan $40 \mathrm{~cm}, 50 \mathrm{~cm}$, dan $60 \mathrm{~cm}$ dengan penambahan GA dapat meningkatkan produksi pucuk teh per perdu. Penelitian yang dilakukan Liang et al. (1996) menjelaskan bahwa giberelin efektif dalam merangsang flushing tanaman teh dan meningkatkan hasil daun teh. Selanjutnya menurut Maudu et al. (2011) bahwa penambahan GA dapat meningkatkan biomassa segar Athrixia phylicoides.

Menurut De Costa et al. (2007) pada daun muda yang sedang berkembang, kapasitas dan efisiensi fotosintesis berkembang secara bertahap. Oleh karena itu, tunas muda dan pucuk bergantung pada daun pemeliharaan untuk suplai proses fotosintesis.

Tabel 6. Pengaruh interaksi tinggi pangkasan dan konsentrasi ZPT terhadap bobot basah pucuk per perdu (g) pada tanaman teh

\begin{tabular}{lcccc}
\hline \multirow{2}{*}{ Tinggi pangkasan } & \multicolumn{4}{c}{ Bobot basah pucuk produksi per perdu $(\mathrm{g})$} \\
\cline { 2 - 4 } & $0 \mathrm{ppm}$ & $60 \mathrm{ppm} \mathrm{BAP}$ & $50 \mathrm{ppm} \mathrm{GA}$ & $60 \mathrm{ppm} \mathrm{BAP}+50 \mathrm{ppm} \mathrm{GA}$ \\
\hline $40 \mathrm{~cm}$ & $8.55 \mathrm{bC}$ & $12.24 \mathrm{aAB}$ & $15.22 \mathrm{aA}$ & $9.62 \mathrm{bBC}$ \\
$50 \mathrm{~cm}$ & $13.15 \mathrm{aA}$ & $13.47 \mathrm{aA}$ & $13.79 \mathrm{aA}$ & $12.43 \mathrm{aA}$ \\
$60 \mathrm{~cm}$ & $9.64 \mathrm{abBC}$ & $8.31 \mathrm{bC}$ & $16.10 \mathrm{aA}$ & $12.32 \mathrm{aB}$ \\
\hline
\end{tabular}

Keterangan: Angka rata-rata yang ditandai dengan huruf yang sama (huruf besar arah horisontal dan huruf kecil arah vertikal) tidak berbeda nyata menurut uji Duncan taraf 5\%

Tabel 7. Rekapitulasi $p$-value pengaruh perlakuan dan interaksinya pada tiap karakter pengamatan tanaman teh

\begin{tabular}{|c|c|c|c|c|c|c|c|}
\hline \multirow{3}{*}{ Karakter } & \multicolumn{7}{|c|}{ Sumber keragaman } \\
\hline & $\begin{array}{c}\text { Jenis } \\
\text { pangkasan } \\
(\mathrm{J}) \\
\end{array}$ & $\begin{array}{c}\text { Tinggi } \\
\text { pangkasan } \\
(\mathrm{P}) \\
\end{array}$ & $\begin{array}{c}\text { Aplikasi } \\
\text { ZPT } \\
(\mathrm{Z})\end{array}$ & $\mathrm{J} \times \mathrm{P}$ & $\mathrm{J} \times \mathrm{Z}$ & $P \times Z$ & $\mathrm{~J} \times \mathrm{P} \times \mathrm{Z}$ \\
\hline & P value & P value & $P$ value & $P$ value & $\mathrm{P}$ value & $P$ value & $P$ value \\
\hline Tinggi tunas & 0.08 & 0.12 & 0.48 & 0.79 & 0.03 & 0.69 & 0.31 \\
\hline Jumlah pucuk burung & 0.21 & 0.02 & 0.92 & 0.29 & 0.73 & 0.27 & 0.37 \\
\hline Dormansi pucuk & 0.59 & 0.91 & 0.00 & 0.31 & 0.08 & 0.47 & 0.08 \\
\hline \multicolumn{8}{|l|}{ Klorofil } \\
\hline Bulan 1 & 0.75 & 0.71 & 0.01 & 0.06 & 0.59 & 0.03 & 0.33 \\
\hline Bulan 2 & 0.68 & 0.59 & 0.04 & 0.16 & 0.41 & 0.01 & 0.27 \\
\hline Bulan 3 & 0.13 & 0.02 & 0.07 & 0.01 & 0.21 & 0.03 & 0.80 \\
\hline Bobot basah pucuk & 0.96 & 0.31 & 0.00 & 0.93 & 0.14 & 0.02 & 0.29 \\
\hline
\end{tabular}

Keterangan: $\mathrm{J}=$ jenis pangkasan; $\mathrm{P}=$ Tinggi pangkasan; $\mathrm{Z}=$ Aplikasi $\mathrm{ZPT} ; p<0.05$ mengindikasikan pengaruh nyata; $p<0.01$ mengindikasikan pengaruh sangat nyata

\section{KESIMPULAN}

Perlakuan jenis pemangkasan bersih dan konsentrasi 60 ppm BAP + 50 ppm GA menunjukkan pertumbuhan terbaik pada tinggi tunas. Tinggi pangkasan $60 \mathrm{~cm}$ dan $60 \mathrm{ppm}$ BAP menunjukkan indeks klorofil daun tertinggi bulan ke3 dibandingkan hasil penelitian sebelumnya (62.5-75.28), sedangkan tinggi pangkasan $60 \mathrm{~cm}$ dan 60 ppm BAP +50 ppm GA memberikan hasil tertinggi terhadap hasil bobot basah pucuk per perdu pada pemetikan produksi ke-4. Secara tunggal, tinggi pangkasan $50 \mathrm{~cm}$ menurunkan jumlah pucuk burung serta konsentrasi 50 ppm GA mempersingkat lamanya masa dormansi pucuk menjadi 22 hari. 


\section{DAFTAR PUSTAKA}

Ahmad, F., F.S. Hamid, S. Sarwar, A. Waheed, S. Aslam, S. Islam, S. Hussain, N. Ahmad, I. Ali. 2014. Effect of different pruning times on the yield of tea (Camellia sinensis L.) under the climatic conditions of Mansehra - Pakistan. Sarhad J. Agric. 30:305-309.

Anjarsari, I.R.D., J.S. Hamdani, C. Suherman, T. Nurmala, H. Syahrian, V.P. Rahadi. 2018. Kadar pati akar dan sitokinin endogen pada tanaman teh menghasilkan sebagai dasar penentuan pemangkasan dan aplikasi zat pengatur tumbuh. J. Kultivasi 17:617-621.

Autio, A.M., M.E. Day. 2016. Cytokinin phytohormonal effects on crown structure. Arbotic. Urban For. 42:120.

Binenbaum, J., R.Weinstain, E.Shani. 2018. Gibberellin localization and transport in plants. Trends Plant Sci. 23:410-421.

Boonman, A., T.L. Pons. 2007. Canopy light gradient perception by cytokinin. Plant Signal. Behav. 2:489491.

Chesney, P., N. Vasquez. 2007. Dynamics of nonstructural carbohydrate reserves in pruned Erythrina poeppigiana and Gliricidia sepium trees. Agrofor. Syst. 69:89-105.

Cortleven, A., T. Schmulling. 2015. Regulation of chloroplast development and function by cytokinin. J. Exp. Bot. 66:4999-5013.

Davies, P.J. 2010. The Plant Hormones: Their Nature, Occurrence, and Functions. Department of Plant Biology. Cornell University, Ithaca, New York 14853, USA.

De Costa, W.A.J.M., A.J. Mohotti, M.A. Wijeratne. 2007. Ecophysiology of tea (Review). Braz. J. Plant Physiol. 19:299-332.

Ebanoidze, N., G. Kutelia. 2018. Formation issues of tea plantations. Internat. Sci. J. Mech. Agric. 2:49-51.

Effendi, D.S., M. Syakir, M. Yusron, Wiratno. 2010. Budidaya dan Pasca Panen Teh. http://perkebunan. litbang.pertanian.go.id [16/01/2018].

Gaspersz, V. 1995. Metode Perancangan Percobaan. CV. ARMICO, Bandung, ID.

Gonbad, R.A., U.R. Sinniah, M.A. Aziz, R. Mohamad. 2014. Influence of cytokinins in combination with
GA3 on shoot multiplication and elongation of tea clone Iran 100 (Camellia sinensis (L.) O. Kuntze). Sci. World J. 2014:1-9.

Halford N. G. 2010. Photosynthate partitioning. p. 67-82. In Davey M.R. (Eds.). Plant Developmental Biology - Biotechnological Perspectives. Springer, Berlin, Heidelberg.

Hörtensteiner, S., B. Kräutler. 2011. Chlorophyll breakdown in higher plants. Biochimica et Biophysica Acta (BBA) Bioenergetics. 1807:977-988.

Hwang, I., J. Sheen, B. Müller. 2012. Cytokinin signalling networks. Annu. Rev. Plant Biol. 63:353-380.

Jones, R.L., P.B. Kaufman. 2008. The role of gibberellins in plant cell elongation. J. Crit. Rev. Plant Sci. 1:23-47.

Kebrom, T.H., W. Spielmeyer, E.J. Finnegan. 2013. Grasses providenew insights into regulation of shoot branching. Trends Plant Sci. 18:4-48.

Kieber, J.J., G.E. Schaller. 2014. Cytokinins. The Arabidopsis Book 12:1-35.

Krishnaraj, T., G. Prabu, A.K.A. Mandal 2020. Synergistic effect of cytokinin and gibberllins stimulate release of dormancy in tea (Camellia sinensis (L.) O. Kuntze) bud. Physiol. Mol. Biol. Plants 26:1035-1045.

Li, Z.X., W.J. Yang, G.J. Ahammed, C. Shen, P. Yan, X. Li, W.Y. Han. 2016. Developmental changes in carbon and nitrogen metabolism affect tea quality in different leaf position. Plant Physiol. Biochem. 106:327-35.

Liang, Y., J. Lu, S. Shang. 1996. Effect of gibberellins on chemical composition and quality of tea (Camellia sinensis L). J. Sci. Food Agric. 72:411-414.

Liu, Z.A., J.P. Yang, Z.C. Yang. 2012. Using a chlorophyll meter to estimate tea leaf chlorophyll and nitrogen contents. J. Soil Sci. Plant Nutr. 12:339-348.

Liu, J., S.M. Sherif. 2019. Hormonal orchestration of bud dormancy cycle in deciduous woody perennials. Front. Plant Sci. 10:1-21.

Mazid, M., T.A.Khan, F.Mohammad. 2011. Cytokinins, A classical multifaceted hormone in plant system. J. Stress Physiol. Biochem. 7:347-368.

Mphagwe, N.I.K. 2009. Lung Pruning : A review for the practice. http://www.cabi.org. [10 April 2020]. 
Nagar, P.K., A. Kumar. 2000. Changes in endogenous gibberellin activity during winter dormancy in tea (Camellia sinensis (L.) O. Kuntze). Acta. Physiol. Plant 22:439-443.

Rademacher, W. 2016. Chemical regulators of Gibberellin status and Their application in plant Production. Annual Plant Reviews 49:359-403.

Roman, H., F.F. Barbier, T. Girault, T. Peron. 2016. Cytokinins are initial targets of light in the control of bud outgrowth. Plant Physiol. 172:489-509.

Saikia, G.K., S. Baruah. 2013. Growth and yield of youg tea plants as affected by pruning and tipping. Agric. Sci. Digest. 33:324-326.

Salisbury, F. B., C.W. Ross. 1995. Fisiologi Tumbuhan (Jilid 3). Penerbit ITB, Bandung, ID.

Santoso, T.B. 2007. Pemangkasan. http://www.montaya. com. [10 Maret 2016].

Santoso, B.B., I.W. Sudika, I.K.D. Jaya, I.G.P.M. Aryana 2014. Hasil biji dan kadar minyak jarak kepyar Lokal Beaq Amor (Ricinus communis L.) pada berbagai umur pemangkasan batang utama. J. Agron. Indonesia 42:244-249.
Thirugnanasambantham, G. Prabu, A.K.A. Mandal. 2020. Synergistic effect of cytokinin and gibberellins stimulates releaseof dormancy in tea (Camellia sinensis (L.) O. Kuntze) bud. Physiol. Mol. Biol. Plants 26:1035-1045.

Maudu, M.E., F.N. Mudau, I.K. Mariga. 2011. The effect of gibberellins on sprouting of cuttings and quality of bush tea (Athrixia phylicoides DC). Afr. J. Biotechnol. 10:8741-6745.

Yoshimitsu, Y. 1970. Control of Tea-Plucking Time by Using Plant Growth Regulators. http://www. jircas. go.jp. [23 Juli 2019].

Yue, C., H. Cao, X. Hao, J. Zeng, W. Qian, Y. Guo, N.Ye, Y. Yang, X. Wang. 2018. Differential expression of gibberellin- and abscisic acid-related genes implies their roles in the bud activity-dormancy transition of tea plants. Plant Cell Rep. 37:425-44.

Zhang, L., C. Shen, J. Wei, W. Han. 2018. Effects of exogenous 6-benzyladenine on dwarfing, shoot branching, and yield of tea plant (Camellia sinensis). HortScience 53:651-655.

Zurcher, E., B. Muller. 2016. Cytokinin synthesis, signaling, and function-advances and new insights. Int. Rev. Cell Mol. Biol. 324:1-38. 